\title{
CORRIGENDUM
}

\section{The causal meaning of Fisher's average effect - CORRIGENDUM}

\section{LEE JAMES, J. AND CHOW CARSON, C.}

doi:10.1017/S0016672313000074. Published online by Cambridge University Press 12 August 2013

In the above published article by Lee and Chow, the following sentence found on page 98, below equation (26) should be deleted:

If genotypes and environments are dependent, this variable is not the same as the population mean $\mathrm{E}(\mathrm{Y})$.

The authors apologize for any confusion this sentence may have caused.

\section{Reference}

Lee, J. J. \& Chow, C. C. (2013). The causal meaning of Fisher's average effect. Genetics Research 95, 89-109, doi: 10.1017/ S0016672313000074. 